\title{
Effect of Ischemia Duration on Autoantibody Response in Rats Undergoing Retinal Ischemia-Reperfusion
}

\author{
Stephanie C. Joachim ${ }^{a}$ Thomas Jehle ${ }^{b, d} \quad$ Nils Boehm ${ }^{c}$ Oliver W. Gramlich ${ }^{c}$ \\ Wolf A. Lagreze $^{b}$ Norbert Pfeiffer ${ }^{c}$ Franz H. Grus ${ }^{c}$ \\ ${ }^{a}$ Experimental Eye Research Institute, Ruhr University Eye Hospital, Bochum, b University Eye Hospital Freiburg, \\ Freiburg, and ${ }^{C}$ Experimental Ophthalmology, Department of Ophthalmology, University Medical Center, \\ Johannes Gutenberg University, Mainz, Germany; ${ }^{d}$ Norfolk and Norwich University Hospitals, Norwich, UK
}

\section{Key Words}

Ischemia-reperfusion - Retinal ganglion cells •

Antibody microarray $\cdot$ Cyclophilin $\cdot \alpha_{5} \beta_{1}$-integrin $\cdot$

Glyceraldehyde-3-phosphate dehydrogenase

\section{Abstract}

Both the innate and the adaptive immune systems are involved in the pathogenic processes following ischemia-reperfusion injury. We analyzed the possible correlation between the duration of ischemia and autoantibody diversification in a model of ocular ischemia. Rats were subjected to 30,45 , or 90 min of ischemia, and retinal ganglion cell (RGC) density and antibody reactivity were analyzed via customized protein microarray slides. After ocular ischemia, significant alterations in antibody response were observed, while increasing exposure caused more severe RGC damage. Distinct antibody responses after ischemia were detected; these alterations comprised decreased reactivities against cyclophilin A and glyceraldehyde-3-phosphate dehydrogenase, possibly due to increased binding of circulating antibodies to debris material. Other antibodies, like those against $\alpha_{5} \beta_{1}$-integrin or $\beta_{2}$-adrenergic receptor, were upregulated after ischemia.

Copyright $\odot 2012$ S. Karger AG, Basel

\section{Introduction}

Transient retinal ischemia is a common model to induce retinal damage in rodents. In the majority of studies, it is achieved through a short-term intraocular pressure increase above the systolic level $[1,2]$. In this model, degeneration of retinal ganglion cells (RGCs) and thinning of the inner retinal layers has been analyzed histologically $[1,2]$, and this damage has also been verified functionally, e.g. through electroretinography $[3,4]$.

Lafuente et al. [5] examined RGC survival rates after different durations of retinal ischemia. In this experiment, rats underwent $30,45,60,90$, or 120 min of retinal ischemia due to ligation of ophthalmic vessels, a method that leads to ischemia without increasing the intraocular pressure. Labeling of RGCs demonstrated significantly lower RGC densities in ischemic eyes compared to controls, at the earliest 5 days after the event. In a recent study, Jehle et al. [6] could confirm that $30,45,60$, and 90 min of retinal ischemia lead to a significant decrease in retrogradely labeled RGCs. They used a technique to raise the intraocular pressure over the systolic blood pressure which results in retinal ischemia.

\section{KARGER}

Fax +4161306 1234

E-Mail karger@karger.ch

www.karger.com (c) 2012 S. Karger AG, Basel

$0030-3747 / 12 / 0482-0067 \$ 38.00 / 0$

Accessible online at:

www.karger.com/ore
Franz H. Grus

Experimental Ophthalmology, Department of Ophthalmology

University Medical Center, Johannes Gutenberg University Mainz

Langenbeckstrasse 1, DE-55101 Mainz (Germany)

Tel. +496131 173 328, E-Mail grus@ eye-research.org 
Table 1. All antigens used for the protein microarrays

\begin{tabular}{|c|c|c|}
\hline Group & Antigen & Source \\
\hline HSPs & $\begin{array}{l}\alpha \text {-A-crystallin } \\
\alpha \text {-B-crystallin } \\
\beta \text {-S-crystallin } \\
\beta \text {-L-crystallin } \\
\gamma \text {-crystallin } \\
\text { HSP } 27 \\
\text { HSP } 60 \\
\text { HSP } 70 \\
\text { chaperonin } 10 \text { (GroES) }\end{array}$ & $\begin{array}{l}\text { Sigma-Aldrich } \\
\text { Sigma-Aldrich } \\
\text { Sigma-Aldrich } \\
\text { Sigma-Aldrich } \\
\text { Sigma-Aldrich } \\
\text { Stressgen } \\
\text { Sigma-Aldrich } \\
\text { Sigma-Aldrich } \\
\text { US Biological }\end{array}$ \\
\hline $\begin{array}{l}\text { CNS } \\
\text { antigens }\end{array}$ & $\begin{array}{l}\text { myelin basic protein (MBP) } \\
\text { S } 100 \text { A4 } \\
\text { neurotrophin-3 (NT-3) } \\
\text { neurotrophin-4 (NT-4) } \\
\text { amyloid precursor protein (APP) } \\
\text { neuron-specific enolase (NSE) } \\
\text { transthyretin (TTR) } \\
\text { contactin-1 } \\
\text { spectrin }\end{array}$ & $\begin{array}{l}\text { Fluka and } \\
\text { Sigma-Aldrich } \\
\text { Sigma-Aldrich } \\
\text { R\&D Systems } \\
\text { R\&D Systems } \\
\text { R\&D Systems } \\
\text { Sigma-Aldrich } \\
\text { Sigma-Aldrich } \\
\text { R\&D Systems } \\
\text { Sigma-Aldrich }\end{array}$ \\
\hline $\begin{array}{l}\text { Structural } \\
\text { antigens }\end{array}$ & $\begin{array}{l}\text { actin } \\
\text { vimentin } \\
\text { glial fibrillary acidic protein (GFAP) } \\
\alpha \text {-synuclein } \\
\gamma \text {-synuclein }\end{array}$ & $\begin{array}{l}\text { Sigma-Aldrich } \\
\text { Progen } \\
\text { US Biological } \\
\text { Sigma-Aldrich } \\
\text { Sigma-Aldrich }\end{array}$ \\
\hline Hormones & $\begin{array}{l}\text { vascular endothelial growth factor } \\
\text { (VEGF) } \\
\text { insulin }\end{array}$ & Sigma-Aldrich \\
\hline $\begin{array}{l}\text { Cellular } \\
\text { metabolism }\end{array}$ & $\begin{array}{l}\text { caspase } 3 \\
\text { annexin } V \\
\text { ubiquitin } \\
\alpha_{2} \text {-macroglobulin }\left(h \alpha_{2} \mathrm{M}\right)\end{array}$ & $\begin{array}{l}\text { R\&D Systems } \\
\text { Sigma-Aldrich } \\
\text { Sigma-Aldrich } \\
\text { R\&D Systems }\end{array}$ \\
\hline $\begin{array}{l}\text { Plasma } \\
\text { proteins }\end{array}$ & $\begin{array}{l}\text { albumin } \\
\text { fibrin } \\
\text { fibronectin }\end{array}$ & $\begin{array}{l}\text { Sigma-Aldrich } \\
\text { Sigma-Aldrich } \\
\text { Sigma-Aldrich }\end{array}$ \\
\hline Enzymes & $\begin{array}{l}\text { glyceraldehyde 3-phosphate } \\
\text { dehydrogenase (GAPDH) } \\
\text { lysozyme } \\
\text { superoxide dismutase (SOD) }\end{array}$ & $\begin{array}{l}\text { Sigma-Aldrich } \\
\text { Sigma-Aldrich } \\
\text { Sigma-Aldrich }\end{array}$ \\
\hline Lipids & $\begin{array}{l}\text { cardiolipin } \\
\text { phosphatidylserine }\end{array}$ & $\begin{array}{l}\text { Sigma-Aldrich } \\
\text { Fluka }\end{array}$ \\
\hline $\begin{array}{l}\text { Other } \\
\text { proteins }\end{array}$ & $\begin{array}{l}\text { glutathione-S-transferase (GST) } \\
\text { clathrin } \\
\text { Jo-1 } \\
\text { transferrin } \\
\text { cylophilin A } \\
\text { proteinase K } \\
\text { protein kinase C (PKC) inhibitor } \\
\alpha_{5} \beta_{1} \text {-integrin } \\
\alpha \text {-1-antitrypsin } \\
\beta_{2} \text {-adrenergic receptor (ADRB2) }\end{array}$ & $\begin{array}{l}\text { Sigma-Aldrich } \\
\text { Sigma-Aldrich } \\
\text { Sigma-Aldrich } \\
\text { Sigma-Aldrich } \\
\text { Sigma-Aldrich } \\
\text { Sigma-Aldrich } \\
\text { Sigma-Aldrich } \\
\text { R\&D Systems } \\
\text { Sigma-Aldrich } \\
\text { Sigma-Aldrich }\end{array}$ \\
\hline
\end{tabular}

Studies on the retina ischemia model have rarely focused on the systemic immune response, although recent findings suggest a complex role of the immune system in accelerating repair and tissue remodeling after ischemiareperfusion in certain organs [7-9]. Several studies link autoantibodies to ischemic diseases [10-12], suggesting that they play a role in events following retinal ischemia and possibly also facilitate further pathologic processes. Yuan et al. [13] observed a correlation of enhanced levels between anti-heat shock protein (HSP) 70 and anti-HSP 60 antibodies and chronic myocardial ischemia. However, the presence of autoantibodies in ocular ischemia needs to be studied in detail.

In a previous study, we analyzed autoantibody alterations up to 4 weeks after 60 min of retinal ischemia [14]. The aim of the present study was to compare the serum antibody response after various periods of retinal ischemia (particularly the severity of the damage). We selected antigens that led to differences in autoantibody response in our preceding analysis as well as additional antigens associated with ischemia [14-16]. Customized protein microarrays were used for antibody detection. This is a quite novel approach that allows the analysis of rather global antibody patterns against purified antigens [17, 18].

In order to study the effect of ischemia duration on autoantibody response, we compared the serum antibody patterns of rats that underwent 30,45 , or 90 min of ocular ischemia followed by reperfusion.

\section{Experimental Procedures}

All procedures were approved by the Animal Care Committee of the University of Freiburg. The animal studies were conducted in accordance with the ARVO Statement for the Use of Animals in Ophthalmic and Vision Research and the European Communities Council Directive of November 24, 1986 (86/609/EEC). Adult male Brown Norway rats (200-250 g) were obtained from Charles River Laboratories (Sulzfeld, Germany). Rats had free access to food and water and were held in cages in temperaturecontrolled rooms with a controlled 12-hour light-dark cycle.

Operations were performed under general anesthesia with isoflurane $/ \mathrm{O}_{2}$. During recovery from anesthesia, animals were placed in separate cages and antibiotic ointment (Refobacin ${ }^{\circledR}$; Merck, Darmstadt, Germany) was applied on the ocular surface. The body temperature was maintained at $37 \pm 0.5^{\circ} \mathrm{C}$ via a heating pad and monitored with a rectal thermometer probe throughout the surgery.

\section{Ischemia-Reperfusion Model}

Rats were anesthetized as described above, and the anterior chamber was cannulated with a 30 -gauge needle connected to a
Joachim/Jehle/Boehm/Gramlich/ Lagreze/Pfeiffer/Grus 
reservoir containing $0.9 \% \mathrm{NaCl}$. The intraocular pressure in the left eye was increased to $120 \mathrm{~mm} \mathrm{Hg}$ for $30(\mathrm{n}=10), 45(\mathrm{n}=9)$, or $90 \mathrm{~min}(\mathrm{n}=5)$. Retinal ischemia was confirmed by retinal edema and stasis in retinal arteries. The needle was removed at the end of the intraocular pressure elevation. Rats that were not reperfused within $5 \mathrm{~min}$, those with incomplete ischemia, or those with suspicion of trauma of the crystalline lens were excluded from the experiments.

\section{Histological Examination}

RGCs were retrogradly labeled 4 days after retinal ischemia by stereotactic injection of the fluorescent tracer FluoroGold ${ }^{\circledR}$ (Fluorochrome, Denver, Colo., USA), dissolved in dimethylformamide, into the superior colliculi of anaesthetized rats using a stereotactic device (Stoelting, Germany). Rats were sacrificed 6 days after labeling by $\mathrm{CO}_{2}$ (i.e. 10 days after ischemia induction). The eyes were removed and fixed in paraformaldehyde. The retinas were dissected, mounted on gelatin-coated glass slides, and embedded. The number of FluoroGold-positive RGCs was quantified under a fluorescence microscope (AxioImager; Carl Zeiss, Jena, Germany). They were counted in 12 distinct areas of 40,000 $\mu \mathrm{m}^{2}$ each in a blinded fashion. The RGC density of each ischemia group was compared to the values of the control group using a two-tailed Student's t test (Statistica V8; Statsoft, Tulsa, Okla., USA). Null hypotheses were rejected at $\mathrm{p}<0.05$.

\section{Protein Microarrays}

Blood was collected from all animals through heart puncture 10 days after ischemia. Samples were also collected from an agematched control group of healthy animals $(n=10)$.

Fifty different highly purified antigens $(1 \mu \mathrm{g} / \mu \mathrm{l}$ diluted in PBS buffer with $1.5 \%$ trehalose) were obtained from Sigma-Aldrich (Munich, Germany), BioMol (Hamburg, Germany), or R\&D Systems (Wiesbaden, Germany). Antigen spotting was performed with a noncontact microarray spotter (sciFLEXARRAYER S3; Scienion, Berlin, Germany). Antigens that were related to ischemic events in the literature, like S-100, myelin basic protein (MBP), glial fibrillary acidic protein, GST, neuron-specific enolase, ubiquitin, cardiolipin, or HSPs, were selected [15, 16, 19, 20]. Some additional antigens were chosen because animals that underwent $60 \mathrm{~min}$ of ischemia in a previous study showed an immune response against these antigens [14].

Microarray preparation and incubation were performed in accordance with previous protocols (table 1) [14]. Briefly, all antigens were spotted in triplicate and spotted slides were blocked with $4 \%$ BSA before incubation with rat serum (dilution 1:250). They were later incubated with a goat anti-rat IgG secondary antibody (Cy-5 labeled; dilution 1:500; Abcam, Cambridge, Mass., USA). Antibody reactivity was detected with an array scanner (Affymetrix, Santa Clara, Calif., USA) before Spotfinder software TM4 (V3.1.1; Dana-Faber Cancer Institute, Boston, Mass., USA) was employed for spot analysis. The mean spot intensity was calculated to compute $\mathrm{z}$-scores for each single spot.

Detection of potential antibody markers and changes in antibody reactivity was performed by multivariate statistical analysis using Statistica software. Differences among the four independent animal groups were calculated by ANOVA, and Tukey's post hoc test was assessed for $\mathrm{p}$ value calculation. Null hypotheses were rejected at $\mathrm{p}<0.05$. Mahalanobis distances were calculated to examine the difference in antibody patterns between the ischemia

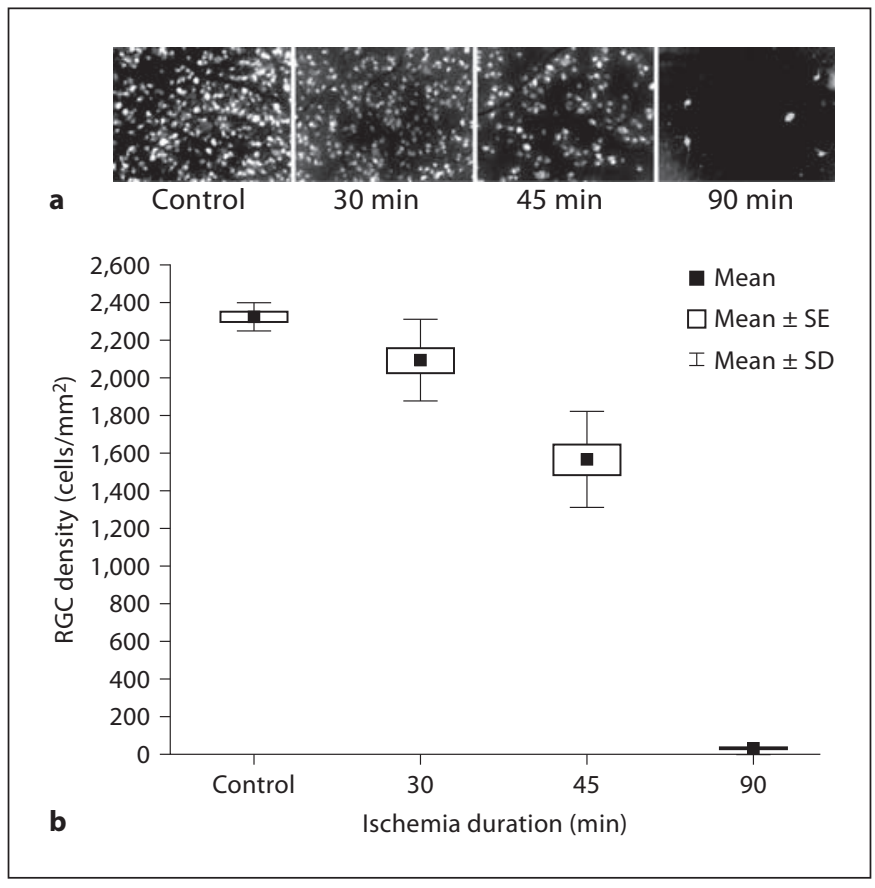

Fig. 1. a RGCs labeled in a retrograde fashion from a control eye as well as from eyes exposed to 30,45 , and $90 \mathrm{~min}$ of retinal ischemia, showing apparent RGC loss. b Mean RGC density ( \pm SD and $\pm S E$ ) in all four groups. There was a significant difference between the RGC counts of the control group and those of all ischemia groups (30 min: $\mathrm{p}=0.04 ; 45 \mathrm{~min}: \mathrm{p}=0.0002$; $90 \mathrm{~min}$ : $\mathrm{p}=0.0002)$.

group and the control group. This is a measure of the divergence between several groups based on multiple characteristics (in this case the antibody responses against several antigens). For each period of ischemia, the distance to the control group was calculated.

Due to the lower number of animals in the 90-min group, this group was excluded from further biomarker calculations. Canonical roots were calculated between the control and the 30min and 45-min groups to display the overall difference in antibody pattern between those groups. The closer the points are to each other, the more similar the antibody patterns of these animals are.

\section{Results}

RGC density was analyzed in retinal flatmounts 10 days after the ischemic event. A mean RGC density of $2,322 \pm 77$ cells $/ \mathrm{mm}^{2}$ (mean $\pm \mathrm{SD}$ ) was counted in control eyes. Cell density decreased with ischemia duration (fig. 1). Thirty minutes of ocular ischemia led to a significantly lower mean RGC density (2,092 \pm 216 cells/ 
Fig. 2. Exemplary protein microarray sections incubated with a control serum sample (a) or samples of animals after $30 \mathrm{~min}$ (b), $45 \mathrm{~min}$ (c), and $90 \mathrm{~min}$ (d) of ischemia. Antigens were all spotted in triplicates. The antibody reactivities against cyclophilin (I 1), $\alpha$-A-crystallin (I 4), HSP 60 (II 3), GST (II 5), GAPDH (III 1), and SOD (IV 3) are displayed.

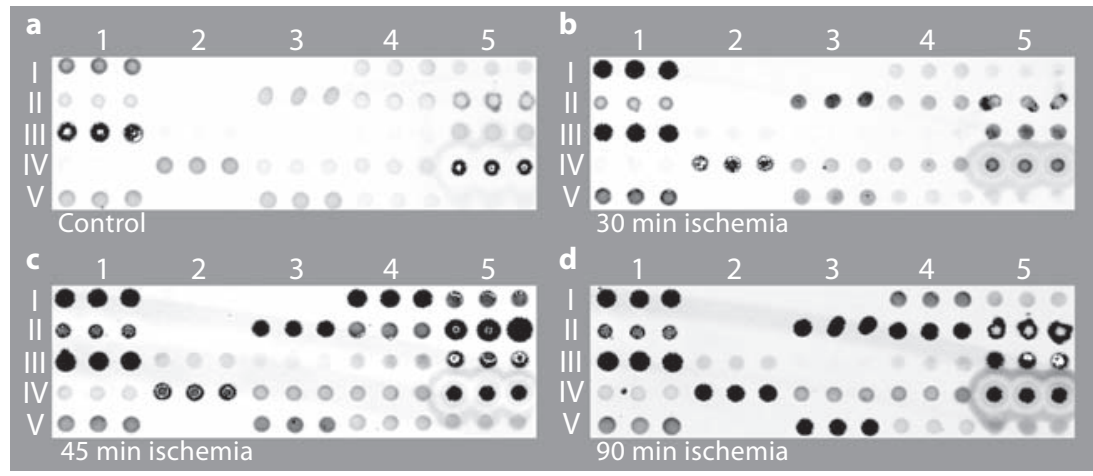

$\left.\mathrm{mm}^{2}, \mathrm{p}=0.04\right)$. A further significant RGC reduction followed from $45 \mathrm{~min}$ of ischemia. The mean cell density of these eyes was $1,567 \pm 252$ cells $/ \mathrm{mm}^{2}(\mathrm{p}=0.0002)$. The most severe ganglion cell loss was observed in retinal flatmounts after eyes underwent 90 min of ischemia. Only $33 \pm 7$ cells $/ \mathrm{mm}^{2}$ were detectable in this group $(\mathrm{p}=$ 0.0002).

A distinct difference in staining intensity was observed for samples from animals that underwent 30, 45,

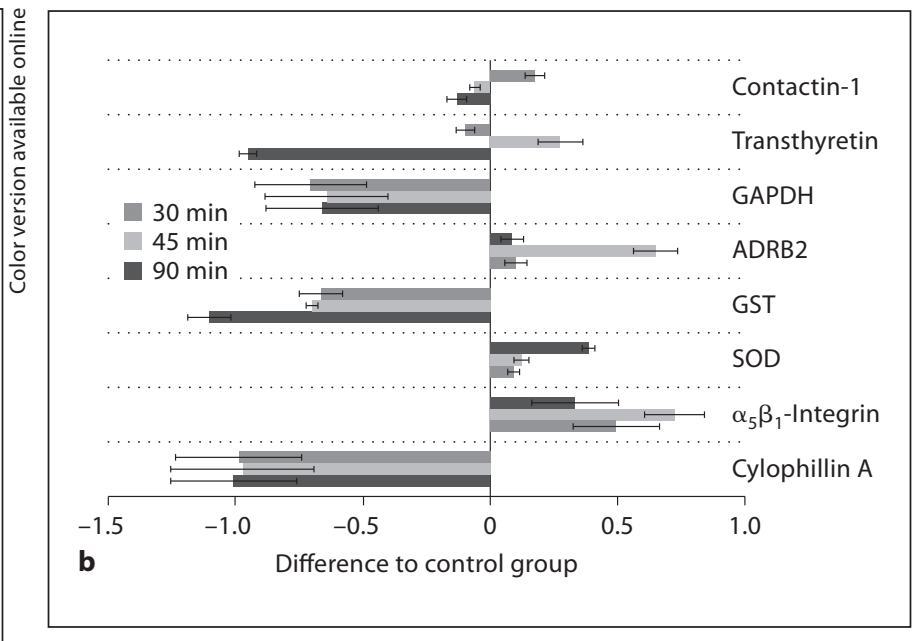

Fig. 3. a Serum antibody reactivity matrices against the tested antigens in control sera and sera of ischemic animals (30, 45, and 90 min). Columns depict rat sera, rows show antigens, and colors correspond to antibody reactivity. A separation of ischemic and control samples was observed. b Differences in antibody reactivity between the control group and each ischemia group for the eight antigens against which the strongest effects were observed are displayed (mean $\pm \mathrm{SE}$ ).

or 90 min of retinal ischemia compared to control samples ( $p<0.005$; fig. 2$)$.

Calculation of the Mahalanobis distances revealed the greatest conformity in antibody reactivities between the control group and animals with $30 \mathrm{~min}$ of ischemia, with a distance of 6.7. The 45-min ischemia group displayed a greater distance (Mahalanobis distance: 7.5 ) and the most different patterns were detected between controls and the 90-min ischemia group (Mahalanobis distance: 7.9), 


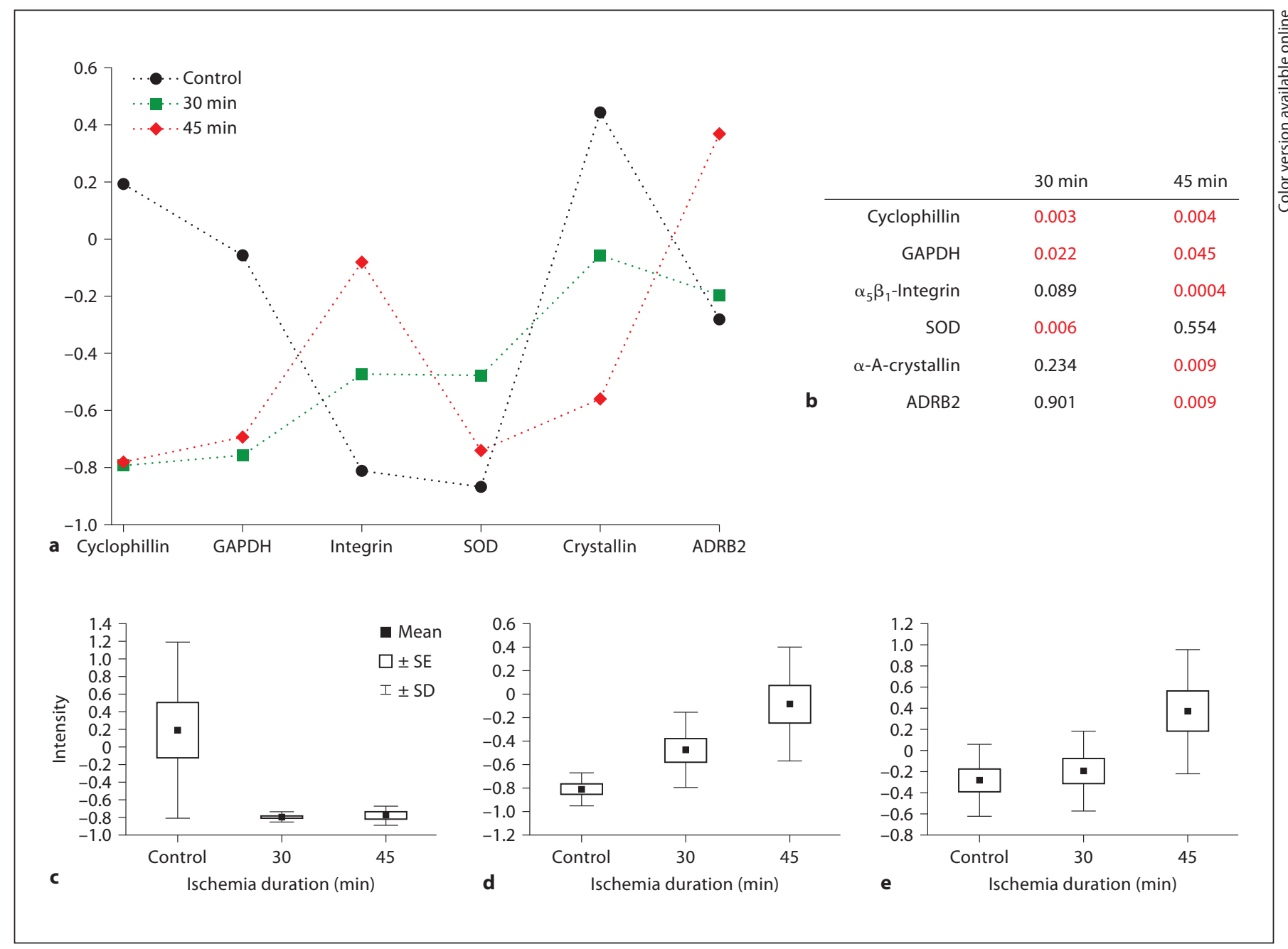

Fig. 4. a The six most prominent biomarkers distinguishing between the control and the 30- and 45-min ischemia groups. The $\mathrm{x}$-axis shows the six biomarkers and the $\mathrm{y}$-axis the intensity of the antibody reactivity. $\mathbf{b} \mathrm{p}$ values between the 30-min or 45-min group and the control group for the six calculated biomarkers between those groups. Box plots displaying the mean antibody reactivities (mean \pm SE) against cyclophilin A (c), $\alpha_{5} \beta_{1^{-}}$ integrin (d), and $\beta_{2}$-adrenergic receptor (e) in the control and 30- and 45-min ischemia groups.

where about $85 \%$ of RGCs died off within 2 weeks. From these date we can conclude that not only the number of RGCs but also the antibody response is affected by ischemia duration. The eight antigens with the most prominent alterations between the four groups were cyclophilin A, $\alpha_{5} \beta_{1}$-integrin, superoxide dismutase, glutathione-Stransferase, $\beta_{2}$-adrenergic receptor, glyceraldehyde-3phosphate dehydrogenase, transthyretin, and contactin-1 (fig. 3b).

When we compared the $30-\mathrm{min}, 45-\mathrm{min}$, and control groups, downregulations of antibodies against cyclophilin A, glyceraldehyde-3-phosphate dehydrogenase, and $\alpha$-A-crystallin were observed in the ischemia groups. However, antibodies against $\alpha_{5} \beta_{1}$-integrin, superoxide dismutase, and $\beta_{2}$-adrenergic receptor were upregulated in the 30- and 45-min ischemia groups in comparison to controls (fig. $4 \mathrm{a}, \mathrm{b}$ ).

Downregulation of antibodies against cylophilin was observed in animals exposed to $30 \mathrm{~min}(\mathrm{p}=0.003)$ and $45 \mathrm{~min}(\mathrm{p}=0.004)$ of ischemia compared to healthy animals (fig. 4c). The box plot in figure $4 \mathrm{~d}$ displays an increase in anti- $\alpha_{5} \beta_{1}$-integrin antibodies in ischemic animals, which was significant in the 45 -min group $(\mathrm{p}=$ 0.0004 ). Autoantibodies against $\beta_{2}$-adrenergic receptor 


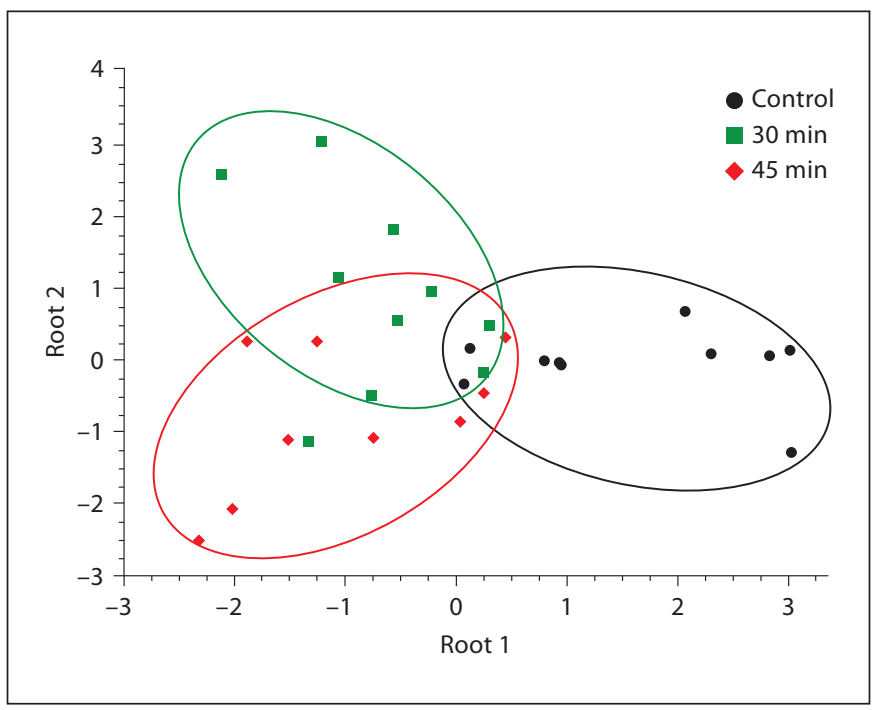

Fig. 5. Canonical roots of the control (black) and 30-min (green) and $45-\mathrm{min}$ (red) ischemia groups. The canonical roots were plotted for each animal and show the similarity of the antibody patterns of these animals. A clear separation between the three groups was observed.

were significantly upregulated in animals exposed to 45 min of ischemia compared to controls ( $\mathrm{p}=0.009$; fig. $4 \mathrm{e})$. The canonical roots show a separation between the 30 min, 45-min, and control groups (fig. 5).

\section{Discussion}

In this animal model, retinal ischemia was induced for 30,45 , or $90 \mathrm{~min}$ via intraocular pressure elevation. In accordance with previous studies where retinal ischemia was induced in animal models, we detected a severe increase in RGC damage with increasing duration of ischemia $[5,6]$. Although models of retinal ischemia have been studied extensively, little focus has been placed on immunological changes. So far, it has been shown that several cytokines, including interleukin, are upregulated in the retina shortly after ischemia $[21,22]$. In a previous study, our group detected autoantibody alterations up to 4 weeks after $60 \mathrm{~min}$ of retinal ischemia [14]. The results presented here confirm that retinal ischemia-reperfusion damage leads to detectable alterations in autoantibody reactivity. The objective of this study was to examine the correlation between the length of the ischemic event and autoantibody diversification. We observed significant alterations in antibody reactivity including decreased reac- tivities against cyclophilin A and glyceraldehyde-3-phosphate dehydrogenase (fig. 4). Decreased reactivities in animals that underwent ischemia compared to controls could reflect loss of circulating IgG antibodies in these animals because they have bound to altered tissue, as already shown by Zephir et al. [23].

In addition, downregulation of antibodies against cyclophilin A was observed (fig. 4c). The cytoplasmic cyclophilin A protein is distributed in neurons throughout the mammalian brain including the visual cortex and the retina [24-26]. It has a fundamental role in cell metabolism [27]. Loss of circulating anti-cyclophilin A antibodies in animals that underwent longer ischemia periods may be a consequence of more severe ischemia-reperfusion damage which leads to increased binding of these antibodies to damaged retinal tissue.

Increased reactivities, as observed for antibodies against $\alpha_{5} \beta_{1}$-integrin or $\beta_{2}$-adrenergic receptor in our study, could be initiated by an ischemic compromise of the blood-retina barrier that certain antigens leak into the peripheral circulation with the consequence of antibody formation, as demonstrated for the central nervous system [28]. Ischemic animals had higher levels of anti$\alpha_{5} \beta_{1}$-integrin antibodies (fig. $4 \mathrm{~d}$ ). Integrins are heterodimers consisting of an $\alpha$ and a $\beta$ subunit. The $\beta_{1}$ and the $\alpha_{5}$ subunits were detectable in retina from human donor eyes, including vessels, various layers of the neural retina [29], and trabecular meshwork [30]. Proliferative diabetic retinopathy vessels expressed integrins [31], and increased $\beta_{1}$-integrin expression in retina from diabetic patients was demonstrated [32]. This alters the interaction of vascular endothelial cells with their basement membranes in the direction of firmer cell-matrix adhesion, compromises the migration and replication critical to the re-endothelialization process, and contributes to microvascular damage and closure. The observed increased levels of antibodies against $\alpha_{5} \beta_{1}$-integrin in our study could possibly be explained by increased systemic $\alpha_{5} \beta_{1^{-}}$integrin levels due to leakage through the retina-blood barrier. As a consequence, animals in our study might have developed increased antibody levels against this protein.

Autoantibodies against $\beta_{2}$-adrenergic receptor were significantly upregulated in animals exposed to $45 \mathrm{~min}$ of ischemia (fig. 4e). $\beta$-Adrenergic receptors are present on endothelial cells of the retina [33], ciliary epithelial cells, trabecular meshwork, and the optic nerve head [3436]. Ninety percent of the $\beta$-adrenergic receptors in the iris-ciliary body are of the $\beta_{2}$ subtype [35]. Autoantibodies against $\beta_{2}$-adrenergic receptor have also been shown 
to be present in patients with myasthenia gravis $[37,38]$, ocular hypertension, and primary open-angle glaucoma [39], indicating an involvement in ocular pathology, for the latter in presumed ischemic neuronal apoptosis.

\section{Conclusions}

Ischemia duration not only influences RGC density but also leads to differences in autoantibody response. Complex antibody response alterations following retinal ischemia include upregulations of the antibody response against $\alpha_{5} \beta_{1}$-integrin and $\beta_{2}$-adrenergic receptor, as well as downregulations of antibodies against cyclophilin A and glyceraldehyde-3-phosphate dehydrogenase with increasing ischemia duration.

\section{Acknowledgements}

This research was supported in part by a grant from the Boehringer Ingelheim Foundation.

We thank the Array Core Facility at the University Medical Center Mainz, Germany, for providing the array scanner.

\section{References}

-1 Adachi M, Takahashi K, Nishikawa M, Miki H, Uyama M: High intraocular pressure-induced ischemia and reperfusion injury in the optic nerve and retina in rats. Graefes Arch Clin Exp Ophthalmol 1996;234:445-451.

- Hughes WF: Quantitation of ischemic damage in the rat retina. Exp Eye Res 1991;53: 573-582.

3 Mukaida Y, Machida S, Masuda T, Tazawa Y: Correlation of retinal function with retinal histopathology following ischemia-reperfusion in rat eyes. Curr Eye Res 2004;28:381389.

4 Grozdanic SD, Sakaguchi DS, Kwon YH, Kardon RH, Sonea IM: Functional characterization of retina and optic nerve after acute ocular ischemia in rats. Invest Ophthalmol Vis Sci 2003;44:2597-2605.

5 Lafuente MP, Villegas-Perez MP, Selles-Navarro I, Mayor-Torroglosa S, Miralles de Imperial J, Vidal-Sanz M: Retinal ganglion cell death after acute retinal ischemia is an ongoing process whose severity and duration depends on the duration of the insult. Neuroscience 2002;109:157-168.

-6 Jehle T, Wingert K, Dimitriu C, Meschede W, Lasseck J, Bach M, Lagreze WA: Quantification of ischemic damage in the rat retina: a comparative study using evoked potentials, electroretinography, and histology. Invest Ophthalmol Vis Sci 2008;49:1056-1064.

7 Jang HR, Ko GJ, Wasowska BA, Rabb H: The interaction between ischemia-reperfusion and immune responses in the kidney. J Mol Med (Berlin) 2009;87:859-864.

-8 Kim BS, Lim SW, Li C, Kim JS, Sun BK, Ahn KO, Han SW, Kim J, Yang CW: Ischemia-reperfusion injury activates innate immunity in rat kidneys. Transplantation 2005;79: 1370-1377.

\9 Gromadzka G, Zielinska J, Ryglewicz D, Fiszer U, Czlonkowska A: Elevated levels of anti-heat shock protein antibodies in patients with cerebral ischemia. Cerebrovasc Dis 2001;12:235-239.
10 Klemp P, Cooper RC, Strauss FJ, Jordaan ER, Przybojewski JZ, Nel N: Anti-cardiolipin antibodies in ischaemic heart disease. Clin Exp Immunol 1988;74:254-257.

-11 Dambinova SA, Khounteev GA, Izykenova GA, Zavolokov IG, Ilyukhina AY, Skoromets AA: Blood test detecting autoantibodies to $\mathrm{N}$-methyl-D-aspartate neuroreceptors for evaluation of patients with transient ischemic attack and stroke. Clin Chem 2003;49: 1752-1762.

12 Chen WH: Anti-beta2-glycoprotein I antibody and hypertension in cerebral ischemia. Clin Appl Thromb Hemost 2004;10:55-60.

13 Yuan J, Yang M, Yao H, Zheng J, Yang Q, Chen S, Wei Q, Tanguay RM, Wu T: Plasma antibodies to heat shock protein 60 and heat shock protein 70 are associated with increased risk of electrocardiograph abnormalities in automobile workers exposed to noise. Cell Stress Chaperones 2005;10:126135.

14 Joachim S, Wax M, Boehm N, Dirk D, Pfeiffer N, Grus F: Up-regulation of antibody response to heat shock proteins and tissue antigens in an ocular ischemia model. Invest Ophthalmol Vis Sci 2011;52:6468-6474.

15 Bornstein NM, Aronovich B, Korczyn AD, Shavit S, Michaelson DM, Chapman J: Antibodies to brain antigens following stroke. Neurology 2001;56:529-530.

16 Whiteley W, Chong WL, Sengupta A, Sandercock P: Blood markers for the prognosis of ischemic stroke: a systematic review. Stroke 2009; 40:e380-e389.

17 Merbl Y, Itzchak R, Vider-Shalit T, Louzoun Y, Quintana FJ, Vadai E, Eisenbach L, Cohen IR: A systems immunology approach to the host-tumor interaction: large-scale patterns of natural autoantibodies distinguish healthy and tumor-bearing mice. PLoS One 2009;4:e6053.
18 Quintana FJ, Farez MF, Viglietta V, Iglesias AH, Merbl Y, Izquierdo G, Lucas M, Basso AS, Khoury SJ, Lucchinetti CF, Cohen IR, Weiner HL: Antigen microarrays identify unique serum autoantibody signatures in clinical and pathologic subtypes of multiple sclerosis. Proc Natl Acad Sci USA 2008;105: 18889-18894.

19 Whiteley W, Tseng MC, Sandercock P: Blood biomarkers in the diagnosis of ischemic stroke: a systematic review. Stroke 2008;39: 2902-2909.

20 Lesnefsky EJ, Slabe TJ, Stoll MS, Minkler PE, Hoppel CL: Myocardial ischemia selectively depletes cardiolipin in rabbit heart subsarcolemmal mitochondria. Am J Physiol Heart Circ Physiol 2001;280:H2770-H2778.

21 Hangai M, Yoshimura N, Yoshida M, Yabuuchi K, Honda Y: Interleukin-1 gene expression in transient retinal ischemia in the rat. Invest Ophthalmol Vis Sci 1995;36:571-578.

22 Hangai M, Yoshimura N, Honda Y: Increased cytokine gene expression in rat retina following transient ischemia. Ophthalmic Res 1996;28:248-254.

23 Zephir H, Almeras L, El Behi M, Dussart P, de Seze J, Steibel J, Trifilieff E, Dubucquoi S, Dessaint JP, Vermersch P, Prin L, Lefranc D: Diversified serum IgG response involving non-myelin CNS proteins during experimental autoimmune encephalomyelitis. J Neuroimmunol 2006;179:53-64.

24 Goldner FM, Patrick JW: Neuronal localization of the cyclophilin a protein in the adult rat brain. J Comp Neurol 1996;372:283-293.

25 Arckens L, Van der Gucht E, Van den Bergh G, Massie A, Leysen I, Vandenbussche E, Eysel UT, Huybrechts R, Vandesande F: Differential display implicates cyclophilin A in adult cortical plasticity. Eur J Neurosci 2003; 18:61-75. 
26 Baudet ML, Hassanali Z, Sawicki G, List EO, Kopchick JJ, Harvey S: Growth hormone action in the developing neural retina: a proteomic analysis. Proteomics 2008;8:389401

27 Handschumacher RE, Harding MW, Rice J Drugge RJ, Speicher DW: Cyclophilin: a specific cytosolic binding protein for cyclosporin A. Science 1984;226:544-547.

28 Cunningham RT, Watt M, Winder J, McKinstry S, Lawson JT, Johnston CF, Hawkins SA, Buchanan KD: Serum neurone-specific enolase as an indicator of stroke volume. Eur J Clin Invest 1996;26:298-303.

29 Brem RB, Robbins SG, Wilson DJ, O’Rourke LM, Mixon RN, Robertson JE, Planck SR, Rosenbaum JT: Immunolocalization of integrins in the human retina. Invest Ophthalmol Vis Sci 1994;35:3466-3474.

-30 Zhou L, Zhang SR, Yue BY: Adhesion of human trabecular meshwork cells to extracellular matrix proteins: roles and distribution of integrin receptors. Invest Ophthalmol Vis Sci 1996;37:104-113.
1 Robbins SG, Brem RB, Wilson DJ, O’Rourke LM, Robertson JE, Westra I, Planck SR, Rosenbaum JT: Immunolocalization of integrins in proliferative retinal membranes. Invest Ophthalmol Vis Sci 1994;35:3475-3485.

32 Roth T, Podesta F, Stepp MA, Boeri D, Lorenzi M: Integrin overexpression induced by high glucose and by human diabetes: potential pathway to cell dysfunction in diabetic microangiopathy. Proc Natl Acad Sci USA 1993;90:9640-9644.

33 Steinle JJ, Booz GW, Meininger CJ, Day JN Granger HJ: Beta 3-adrenergic receptors regulate retinal endothelial cell migration and proliferation. J Biol Chem 2003;278:2068120686.

34 Wax MB, Molinoff PB, Alvarado J, Polansky $\mathrm{J}$ : Characterization of beta-adrenergic receptors in cultured human trabecular cells and in human trabecular meshwork. Invest Ophthalmol Vis Sci 1989;30:51-57.
35 Wax MB, Molinoff PB: Distribution and properties of beta-adrenergic receptors in human iris-ciliary body. Invest Ophthalmol Vis Sci 1987;28:420-430.

36 Tran VT: Human retinal pigment epithelial cells possess beta 2-adrenergic receptors. Exp Eye Res 1992;55:413-417.

37 Xu BY, Pirskanen R, Lefvert AK: Antibodies against beta 1 and beta 2 adrenergic receptors in myasthenia gravis. J Neuroimmunol 1998; 91:82-88.

38 Eng H, Magnusson Y, Matell G, Lefvert AK, Saponja R, Hoebeke J: Beta 2-adrenergic receptor antibodies in myasthenia gravis. J Autoimmun 1992;5:213-227.

39 Junemann AG, Herrmann M, Sheriff A, Stergiopoulos P, Schlotzer-Schrehardt U, Kruse FE, Kunze R, Wallukat G: Agonistic autoantibodies against beta2-adrenergic receptors in ocular hypertension and primary openangle glaucoma. Invest Ophthalmol Vis Sci 2006;47:3384. 